\title{
Characteristics and Properties of As-HIP P/M Alloy 720
}

J. H. Moll and J. J. Conway

Crucible Materials Corporation

\begin{abstract}
$\underline{\text { Abstract }}$
Alloy 720 is currently being used as a conventional cast and wrought material for turbine engine disks. Recently, the alloy was evaluated as an extrude plus isothermally forged (E+I) P/M material with excellent results. In the present work, P/M 720 was evaluated in the hotisostatically-pressed plus heat treated (as-HIP) condition since this type of processing represents the potential for lower cost through elimination of the extrusion and forging steps to produce near-net shapes. Tensile, stress rupture and LCF properties were evaluated. The results compare favorably with those of $(\mathrm{E}+\mathrm{I})$ P/M material and indicate that as-HIP P/M Alloy 720 may be suited for engine application.
\end{abstract}




\section{$\underline{\text { Introduction }}$}

Alloy 720 is a high strength nickel based superalloy which was originally developed as a wrought turbine blade alloy for industrial turbines (1). The alloy is currently being used in the cast and wrought form as a turbine disk alloy. More recently, the alloy has been evaluated as a powder metallurgy $(\mathrm{P} / \mathrm{M})$ material processed using extrusion plus isothermal forging $(E+I)(2,3)$. Reportedly, the alloy has excellent fatigue crack growth resistance and is being strongly considered for application in turbine disks for small to medium gas turbine engines. As-HIP refers to hot-isostaticallypressed plus heat treated material processed without further thermomechanical treatment. A major benefit of as-HIP processing is lower cost through the elimination of extrusion and isothermal forging and the reduction of input material through near-net shape capability. This approach has been successfully applied to Rene 95 and Low Carbon Astroloy with over 100,000 turbine engine components flying world wide (5). The objective of this work was to evaluate the mechanical properties of as-HIP Alloy 720 to determine if this alloy could be used in as-HIP condition in engine applications.

\section{Billet Manufacture}

Material used in this program was from 6.5-inch (165-mm) diameter billet produced using argon atomized Alloy 720 powder consolidated by hot-isostatic-pressing followed by heat treatment. The process is shown schematically in Figure 1.

In powder manufacture, vacuum induction melted metal is delivered to the atomizer as a thin stream which is impinged upon by high pressure argon gas. The metal stream breaks up via the transfer of kinetic energy to surface energy. Spherical droplets are formed due to surface tension and solidify in the range of $10^{4}$ to $10^{6} \mathrm{C} / \mathrm{sec}$. For the current study, the powder was produced as several $5000 \mathrm{lb}$ heats which were subsequently combined to make a master powder blend. Once atomized, the powder was screened to -270 mesh $(-53$ $\mu \mathrm{m})$. All powder processing was performed in equipment and systems made from stainless steel. Specially designed valves and powder transfer bins were also used to insure powder cleanliness.

The powder was subsequently loaded into mild steel containers which were then outgased and sealed. The containers were HIPed at $2065 \mathrm{~F}(1129 \mathrm{C}) / 15 \mathrm{ksi}(103 \mathrm{MPa}) / 4 \mathrm{hr}$. The composition of the resulting P/M 6.5-inch $(165 \mathrm{~mm})$ diameter billet is given in Table I.

Table I Composition of P/M Alloy720

\begin{tabular}{|l|c||l|c|}
\hline \multicolumn{4}{|c|}{ Composition - Wt \% } \\
\hline \hline Carbon & 0.010 & Tungsten & 1.28 \\
\hline Chromium & 16.57 & Boron & 0.012 \\
\hline Cobalt & 14.71 & Zirconium & 0.038 \\
\hline Molybdenum & 3.00 & Aluminum & 2.49 \\
\hline Titanium & 5.02 & Nickel & Balance \\
\hline
\end{tabular}

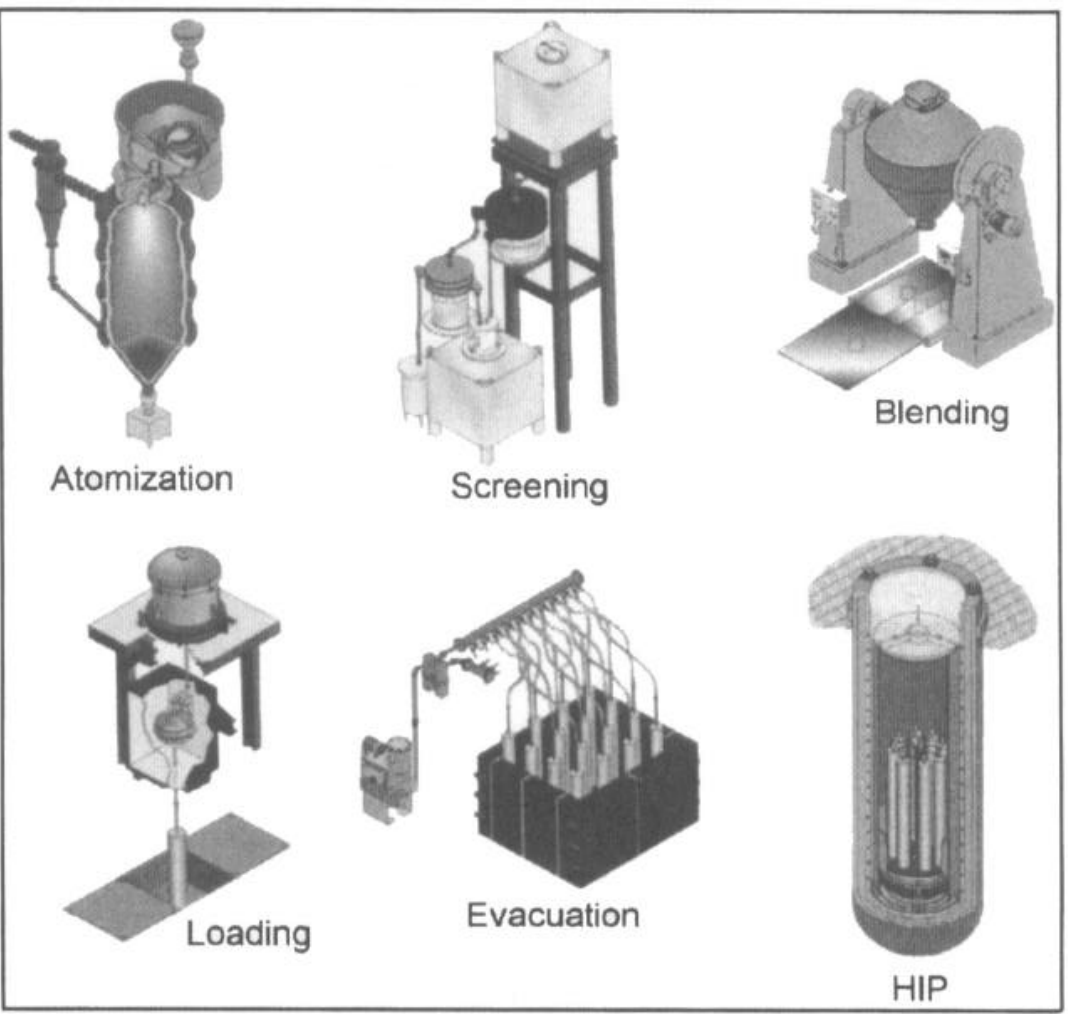

Figure 1. Schematic showing the steps involved in the as-HIP $\mathrm{P} / \mathrm{M}$ process 
Billet Evaluation

\section{$\underline{\text { Microstructure }}$}

Initially, a solution treatment study was conducted in the temperature range of $2000 \mathrm{~F}$ (1193C) to $2150 \mathrm{~F}$ (1177C). Microstructural examination showed the $\gamma$ ' solvus temperature for the material to be between $2075 \mathrm{~F}(1135 \mathrm{C})$ and $2100 \mathrm{~F}(1149 \mathrm{C})$. This is congruent with that reported in the literature (5). As shown in Table II, heat treatment below the solvus temperature resulted in a fine uniform structure with a grain size of ASTM 10 and finer (Figure 2a). Heat treatment above the solvus resulted in a grain size of ASTM 8.5-9 which was stable up to at least 2150F (1177C) (Figure 2b). Based on these studies, 2040F (1116C) was selected as a sub-solvus solution treatment to maintain a fine uniform grain structure for high yield strength. A super-solvus treatment of $2150 \mathrm{~F}(1177 \mathrm{C})$ was selected to increase the grain size and maximum solutioning of second phase particles for optimal stress rupture properties.

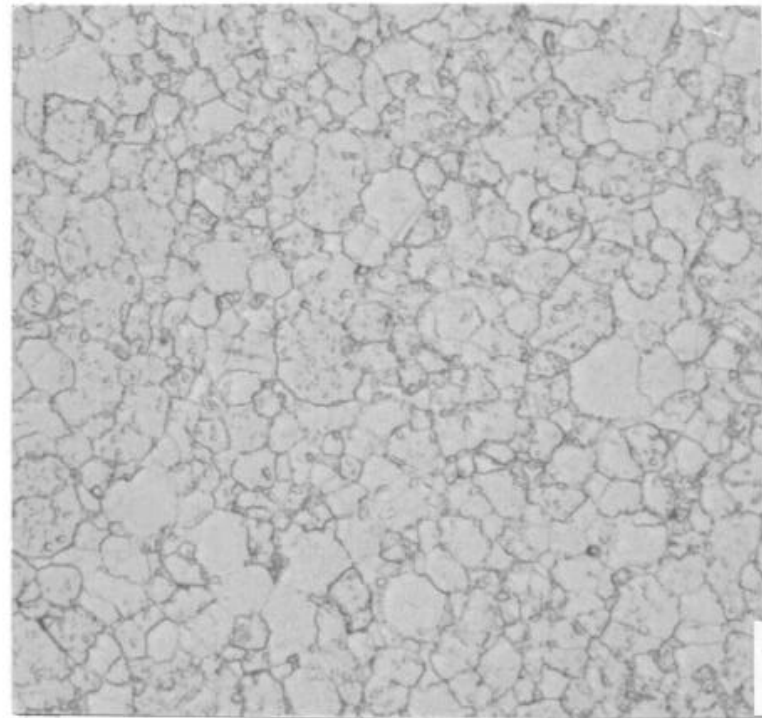

(a)
Table II Effect of Solution Treatment Temperature on Grain Size of As-HIP Alloy 720

\begin{tabular}{|c||c|c|}
\hline \multirow{2}{*}{$\begin{array}{c}\text { Solution } \\
\text { Treatment } \\
\text { Temperature }\end{array}$} & \multicolumn{2}{c|}{ Average Grain Size } \\
\cline { 2 - 3 } & ASTM No. & $\mu \mathrm{m}$ \\
\hline \hline 2000F (1093C) & 11.0 & 8.0 \\
\hline $2025 \mathrm{~F}(1107 \mathrm{C})$ & 10.5 & 9.4 \\
\hline $2050 \mathrm{~F}(1121 \mathrm{C})$ & 10.5 & 9.4 \\
\hline $2075 \mathrm{~F}(1135 \mathrm{C})$ & 10.0 & 11.0 \\
\hline $2100 \mathrm{~F}(1144 \mathrm{C})$ & 9.0 & 16.0 \\
\hline $2125 \mathrm{~F}(1163 \mathrm{C})$ & 8.5 & 18.9 \\
\hline $2150 \mathrm{~F}(1177 \mathrm{C})$ & 8.5 & 18.9 \\
\hline
\end{tabular}

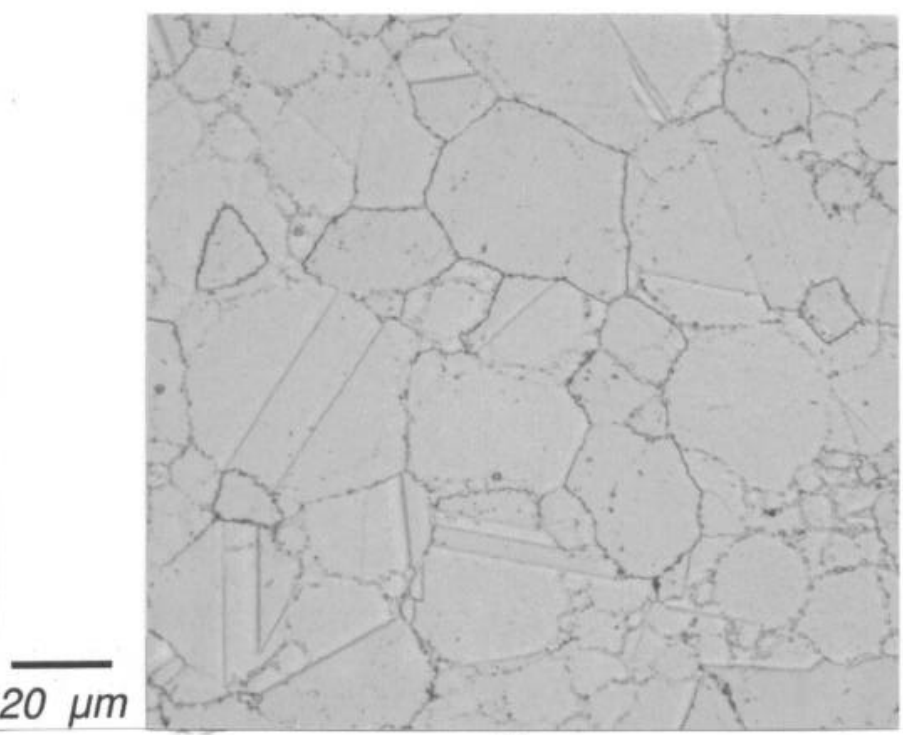

(b)

Figure 2. Microstructure of as-HIP P/M Alloy 720 solution treated at (a) $2050 \mathrm{~F}$ (1121C) and (b) $2150 \mathrm{~F}$ (1177C)

\section{Mechanical Properties}

To determine the effect of grain size on the mechanical properties of as-HIP Alloy 720, tensile, creep-rupture and low cycle fatigue (LCF) properties were evaluated for both sub-solvus and supersolvus solution treated material. Following solution treatment, the materials were aged at $1400 \mathrm{~F}(760 \mathrm{C}) / 8 \mathrm{hr}+1200 \mathrm{~F}(649 \mathrm{C}) / 24 \mathrm{hr}$.

Tensile tests were conducted over the temperature range from roomtemperature to $1600 \mathrm{~F}(871 \mathrm{C})$. Figure 3 shows the effect solution treatment temperature on the tensile properties of as-HIP 720 at room temperature and $1000 \mathrm{~F}(538 \mathrm{C})$, respectively. As expected, sub-solvus solution treatment results in higher strength and ductility than super-solvus solution treatment due to differences in grain size. The tensile properties from room temperature to $1600 \mathrm{~F}(871 \mathrm{C})$ for sub-solvus and super-solvus treatments are shown in Figures 4 and 5 , respectively. As can be noted, as-HIP Alloy 720 retains excellent strength and ductility up to at least $1200 \mathrm{~F}$ (1121C). As shown in Figure 6, the tensile properties also compare favorably with $\mathrm{E}+\mathrm{I} \mathrm{P} / \mathrm{M}$ material.

Stress-rupture properties were determined in the $1200 \mathrm{~F}(1121 \mathrm{C})$ to $1450 \mathrm{~F}(788 \mathrm{C})$ temperature range The data for as-HIP along with those for E+I P/M Alloy 720 are summarized in Figure 7. As can be noted, sub-solvus treated as-HIP Alloy 720 is quite comparable to $\mathrm{E}+\mathrm{I} \mathrm{P} / \mathrm{M}$ material over the entire temperature range. Supersolvus treatment resulted in a significant increase in rupture strength primarily due to the coarser grain size which results from this treatment.

Smooth bar LCF tests were conducted on as-HIP Alloy 720 at $1000 \mathrm{~F}(538 \mathrm{C})$. The tests were conducted at an $\mathrm{R}=0$ and a frequency of $20 \mathrm{cpm}$ in strain control. The results are given in Table III and summarized in Figure 8. As shown in Figure 9, the strain for a 30,000 cycle mean initiation life of $0.9 \%$ compares favorably with that reported for E+I P/M Alloy 720 and is higher than that of conventional cast and wrought Alloy 720 (2). 


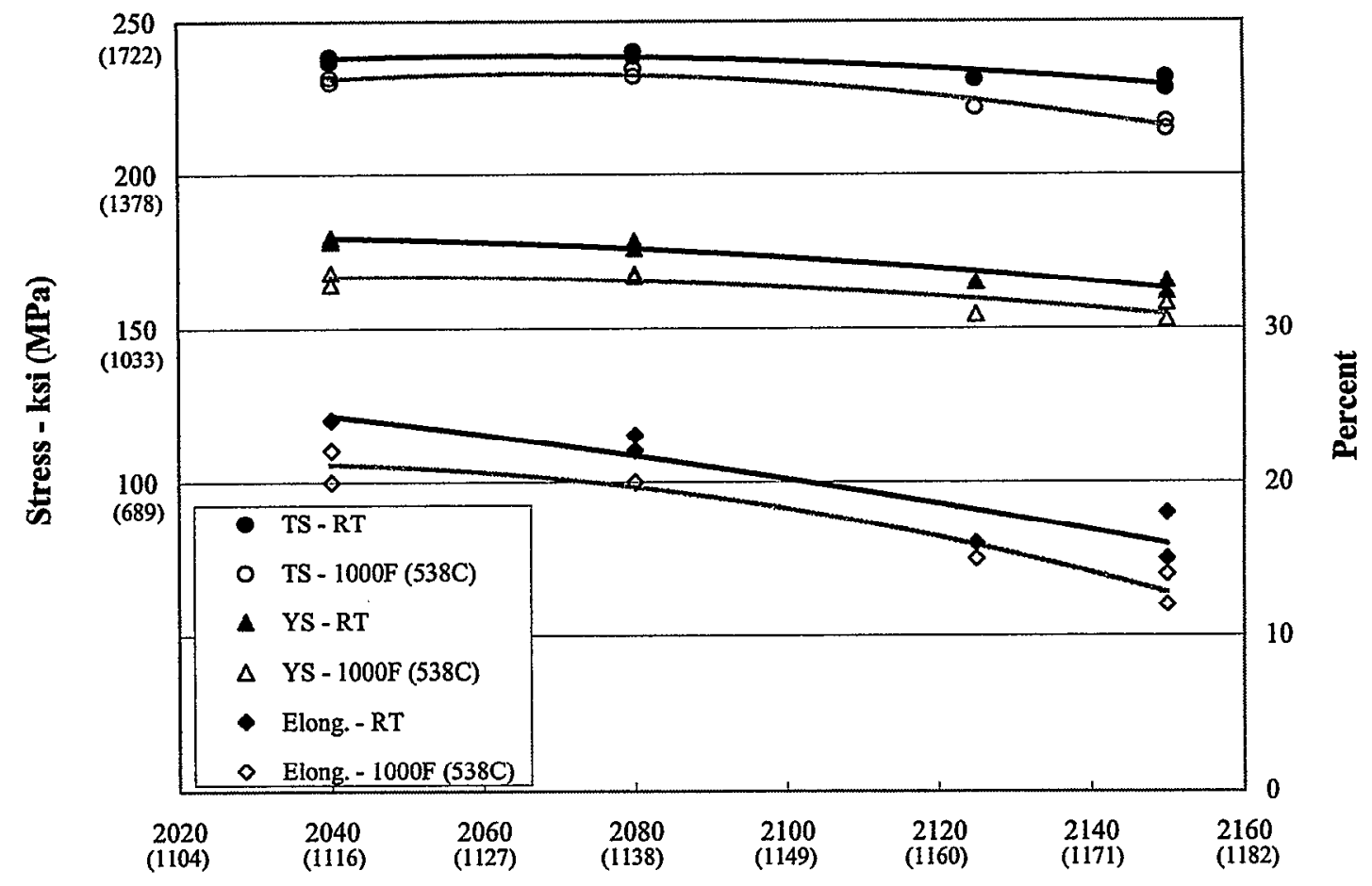

Solution Treatment Temperature- F (C)

Figure 3. Effect of solution treatment temperature on room temperature and $1000 \mathrm{~F}(538 \mathrm{C})$ tensile properties of as-HIP Alloy 720. Material was solution treated at the indicated temperature and then aged at $1400 \mathrm{~F}(760 \mathrm{C}) / 8 \mathrm{hr}+1200 \mathrm{~F}(649 \mathrm{C}) / 24 \mathrm{hr}$.

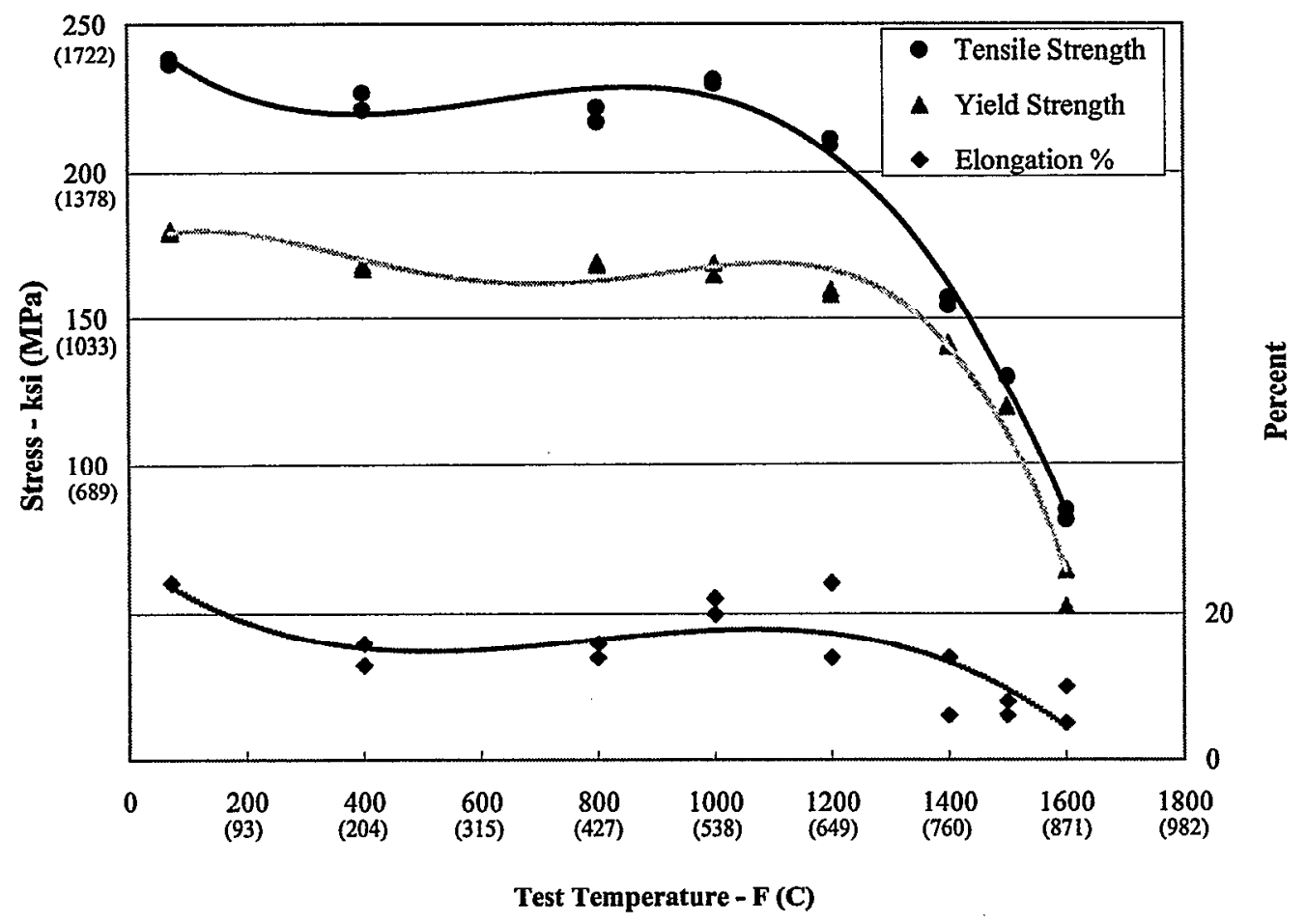

Figure 4. Tensile properties of as-HIP Alloy 720 sub-solvus solution treated at $2040 \mathrm{~F}(1116 \mathrm{C})$ and aged at $1400 \mathrm{~F}(760 \mathrm{C}) / 8 \mathrm{hr}+1200 \mathrm{~F}(649 \mathrm{C}) / 24 \mathrm{hr}$. 


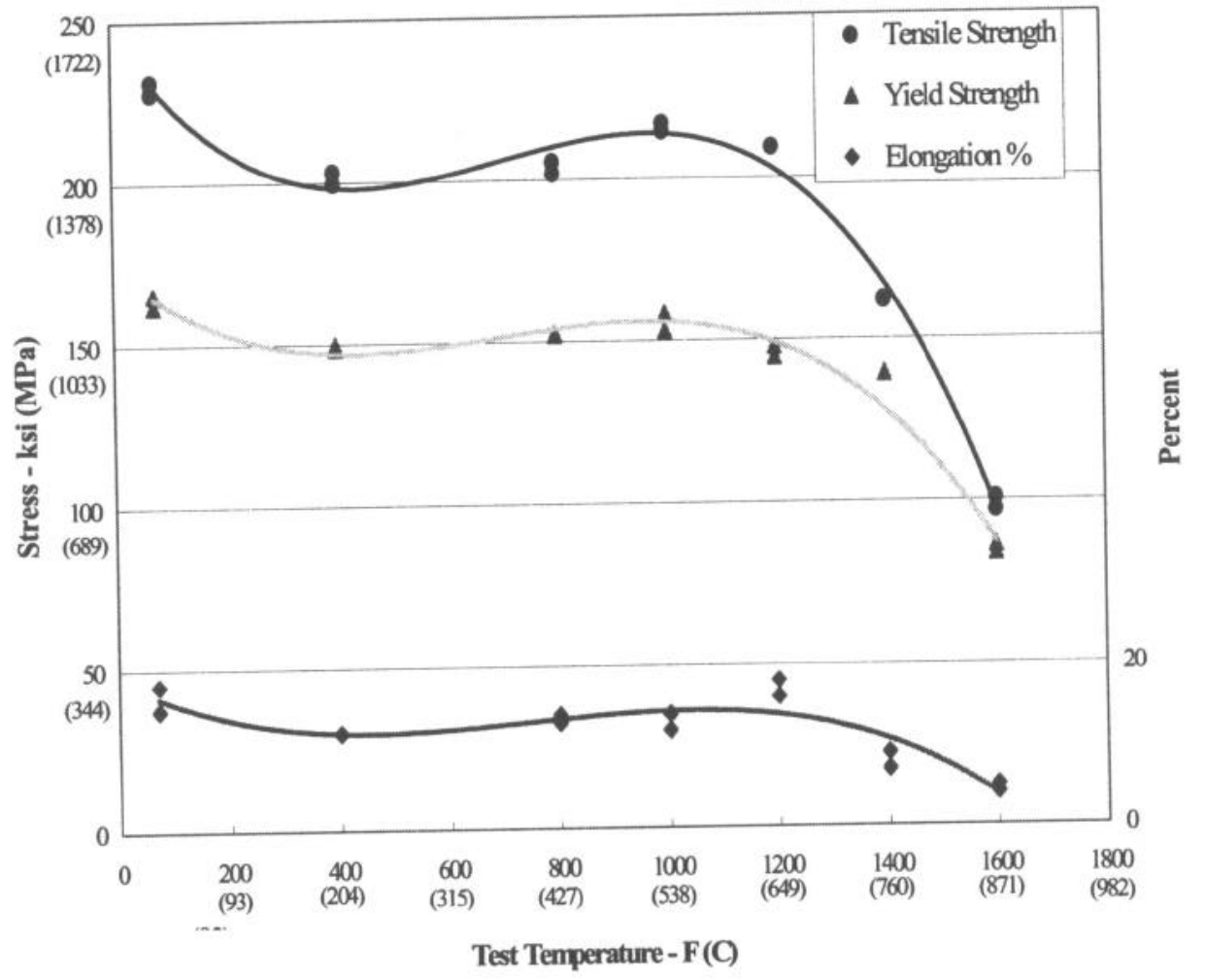

Figure 5. Tensile properties of as-HIP Alloy 720 super-solvus solution treated at $2150 \mathrm{~F}(1177 \mathrm{C})$ and aged at $1400 \mathrm{~F}(760 \mathrm{C}) / 8 \mathrm{hr}+1200 \mathrm{~F}(649 \mathrm{C}) / 24 \mathrm{hr}$.

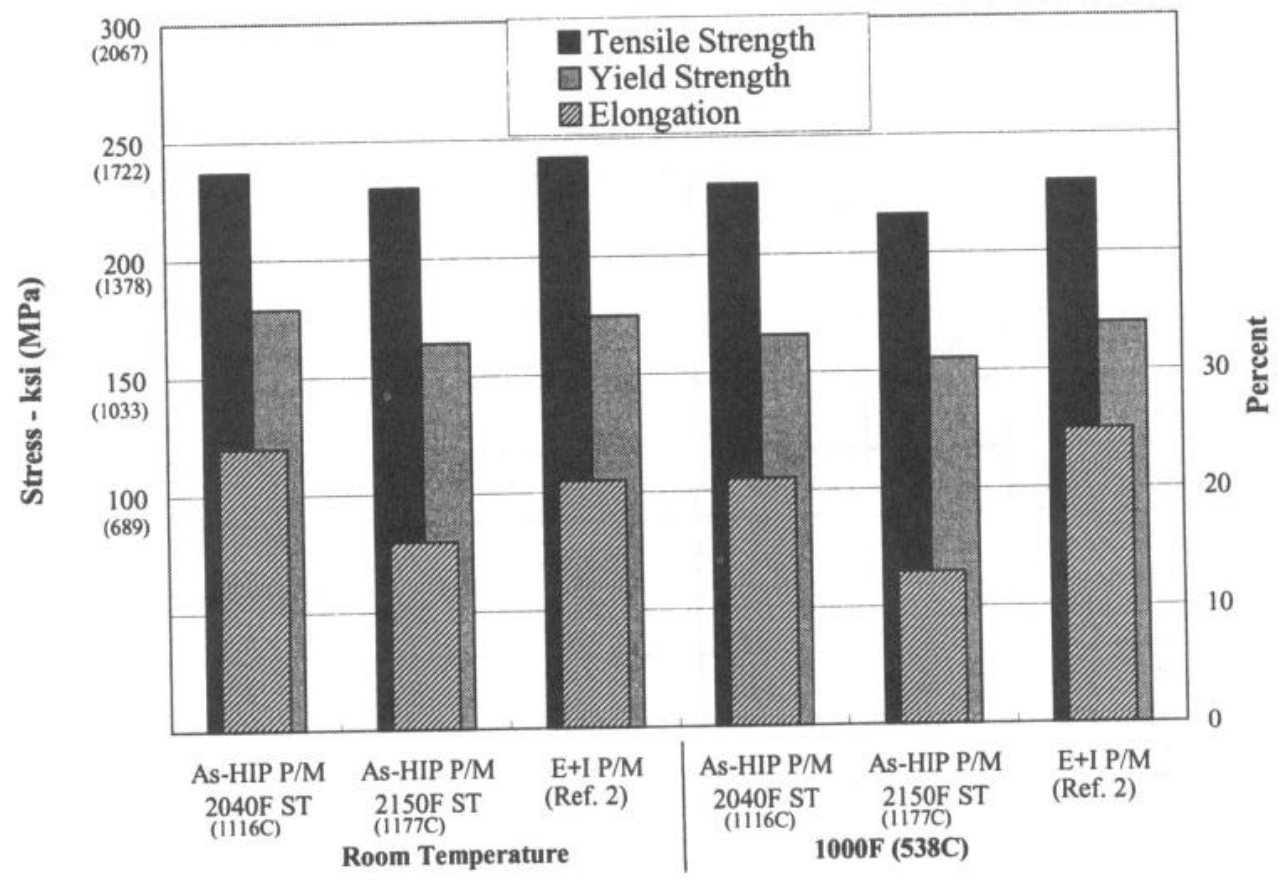

Figure 6. Comparison of the tensile properties of as-HIP Alloy 720 with E+I P/M material in the solution treated and aged condition. 


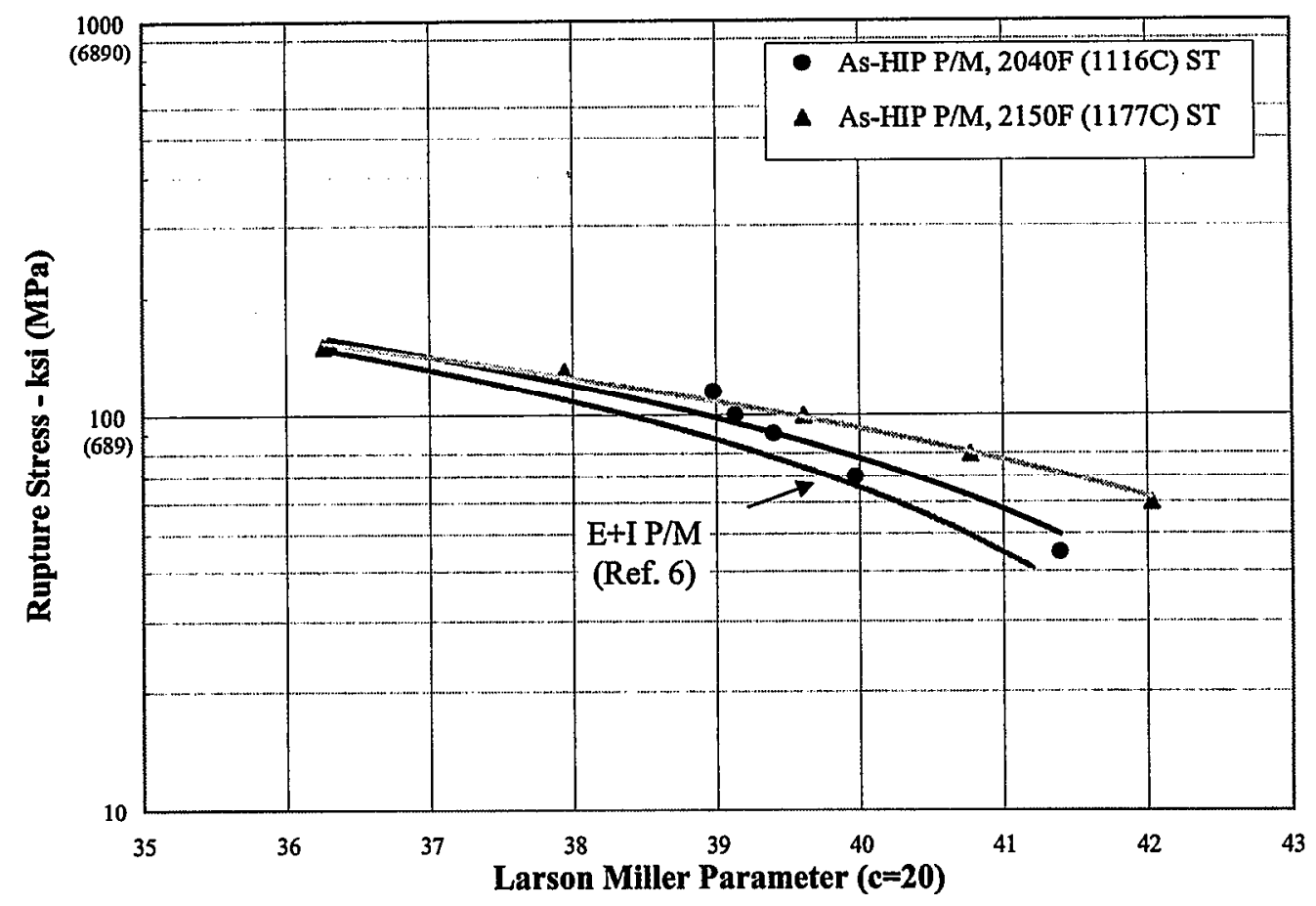

Figure 7. Stress rupture properties of as-HIP P/M and E+I P/M Alloy 720 in the solution treated and aged condition.

Table III Results of 1000F (538C) LCF Tests of As-HIP Alloy 720

\begin{tabular}{|c|c|c|c|c|c|}
\hline \multirow{2}{*}{$\begin{array}{c}\text { Solution } \\
\text { Temperature }\end{array}$} & \multirow{2}{*}{$\begin{array}{c}\text { Strain } \\
\text { Range } \\
(\%) \\
\end{array}$} & \multirow{2}{*}{$\begin{array}{l}\text { Cycles to } \\
\text { Crack } \\
\text { Initiation } \\
\end{array}$} & \multicolumn{3}{|c|}{ Fracture Initiation Source } \\
\hline & & & $\begin{array}{c}\text { Size } \\
\text { (milli-inches }^{2} \text { ) } \\
\end{array}$ & Type & Composition \\
\hline $2040 \mathrm{~F}(1116 \mathrm{C})$ & 0.86 & 80,703 & 3.58 & Ccramic & $\mathrm{Al}, \mathrm{O}$ \\
\hline $2040 \mathrm{~F}(1116 \mathrm{C})$ & 0.86 & 80,881 & 2.32 & Ceramic & $\mathrm{Al}, \mathrm{O}$ \\
\hline $2040 \mathrm{~F}(1116 \mathrm{C})$ & 0.90 & 7,635 & 0.78 & Ceramic & $\mathrm{Al}, \mathrm{O}$ \\
\hline $2040 F(1116 C)$ & 0.90 & 45,022 & 3.54 & Ceramic & $\mathrm{Al}, \mathrm{Mg}, \mathrm{Zr}, \mathrm{O}$ \\
\hline $2040 F(1116 C)$ & 1.00 & 7,843 & 0.60 & Pore & - \\
\hline $2040 \mathrm{~F}(1116 \mathrm{C})$ & 1.00 & 8,130 & 0.48 & Pore & - \\
\hline $2150 \mathrm{~F}(1177 \mathrm{C})$ & 0.86 & 11,450 & - & Grain & - \\
\hline $2150 \mathrm{~F}(1177 \mathrm{C})$ & 0.92 & 11,118 & - & Grain & - \\
\hline $2150 \mathrm{~F}(1177 \mathrm{C})$ & 1.00 & 6,485 & - & Grain & - \\
\hline
\end{tabular}

* Material tested at $\mathrm{K}_{\mathrm{t}}=0, \mathrm{R}=0,20 \mathrm{cpm}$ under strain control 


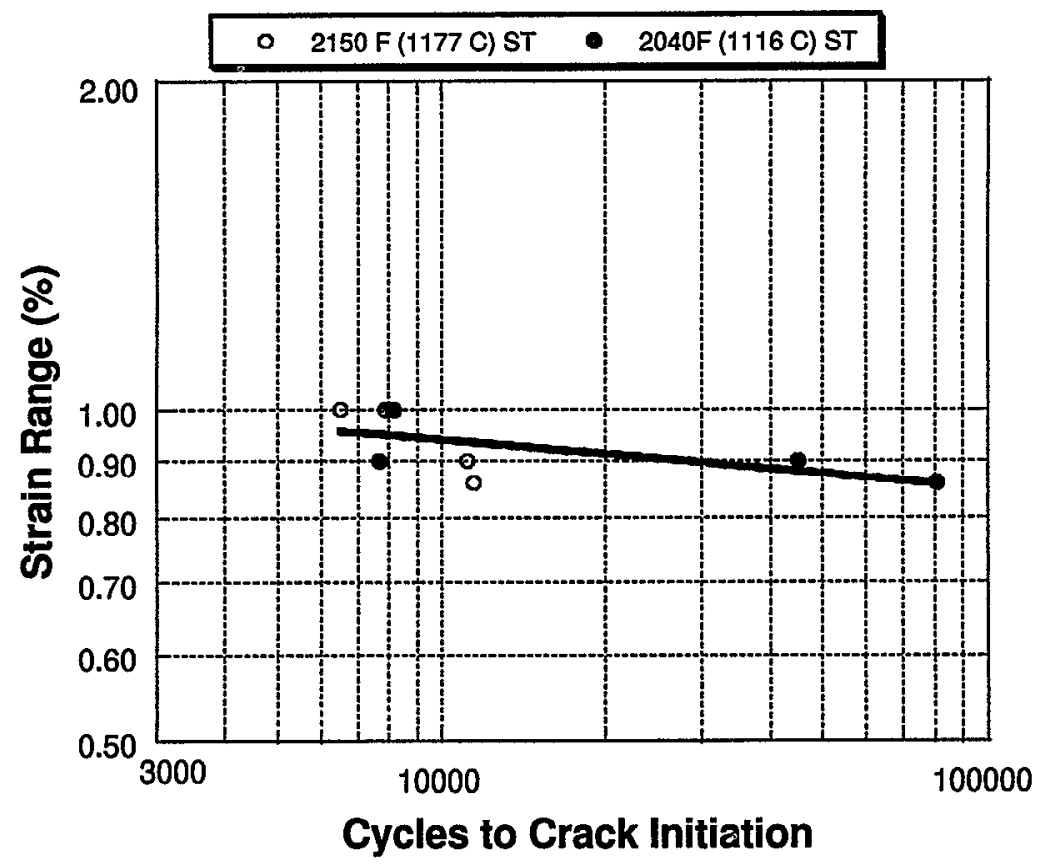

Figure 8. Low cycle fatigue properties of as-HIP P/M Alloy 720 at $1000 \mathrm{~F}(538 \mathrm{C})$. Material was solution treated at the indicated temperature and aged at $1400 \mathrm{~F}(760 \mathrm{C}) / 8 \mathrm{hr}+1200 \mathrm{~F}(649 \mathrm{C}) / 24 \mathrm{hr}$.

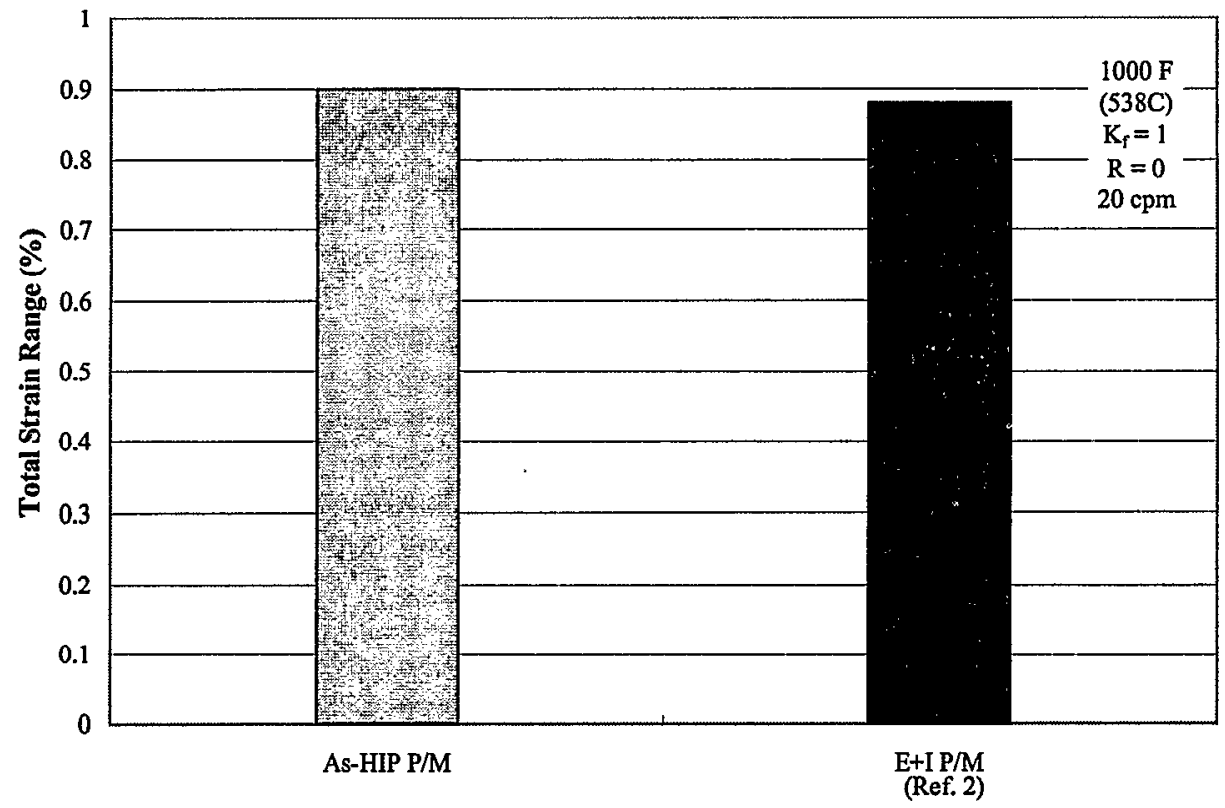

Figure 9. Comparison of as-HIP and E+I P/M Alloy 720 of total strain for 30,000 cycles mean initiation life. 
Fracture surfaces of LCF specimens were examined to determine the features of fracture initiation sites. The results are included in Table III. The LCF bars from sub-solvus treated material failed at ceramic inclusions or pores while super-solvus treated material failed at grains. The inclusion size, type and composition observed as fracture initiation sites are similar to those observed in other $E+I$ $\mathrm{P} / \mathrm{M}$ superalloys produced from -270 mesh powder.

\section{$\underline{\text { Summary and Conclusions }}$}

As-HIP Alloy 720 was evaluated for tensile, stress rupture and low cycle fatigue properties at room- and elevated-temperatures. The results show that the material exhibits excellent properties over a wide temperature range. The properties compare favorably with conventional ingot metallurgy and E+I P/M material.

The results of the work conducted to date indicate that as-HIP P/M Alloy 720 may be suited for engine applications. Additional testing is planned to further evaluate the low cycle fatigue behavior and fatigue crack growth resistance of this material to more fully evaluate its potential.

\section{References}

1. H. Pushnik, G. Zeiler, J. Fladisher, W. Eber and K. Keienburg, "Udimet 720 Turbine Blades Production and Properties", Evolution of Advanced Materials, Associazione Italiana di Metallurgia, Milano, 1989.

2. K. A. Green, J. A. Lemsky and R. M. Gasior, Development of Isothermally Forged P/M Udimet 720 for Turbine Disk Applications", Superalloys 1996, R. D.
Kissinger, et al (eds), The Minerals, Metals \& Materials Society, 1996.

3. H. Hattory, M. Takekawa, D. Furrer and R.J. Noel, Evaluation of P/M U720 for Gas Turbine Application", Superalloys 1996, R. D. Kissinger, et al (eds), The Minerals, Metals \& Materials Society, 1996.

4. J. H. Moll, J. J. Conway and B. J. McTiernan, "As-HIP P/M Superalloys: A Technical and Commercial Success" Advances in Powder Metallurgy and Particulate Materials, MPIF, 1999.

5. J. Hyzak, R. Singh, J. Morra and T. Howson, "The Microstructural Response of As-HIP P/M U-720 to Thermomechanical Processing", Superalloys 1992, S. Antolovich et al, (eds), The Minerals, Metals \& Materials Society, 1992.

6. "Powder Metal Udimet 720 Turbine Engine Components" ASAATCOM Report No. TR-96-F001, April 1996.

The material contained in this paper is intended for general information only and should not be used in relation to any specific application without independent study and determination of its applicability for the intended application. Any one making use of this material or relying thereon, assumes all risk and liability arising therefrom. 